\title{
DA ANÁLISE SEMIÓTICA À AULA DE LEITURA: O PERCURSO GERATIVO NO CONTEXTO ESCOLAR
}

\author{
FROM SEMIOTIC ANALYSIS TO READING CLASSES: \\ THE GENERATIVE COURSE IN THE SCHOOL CONTEXT
}

\author{
Sonia MERITH-CLARAS ${ }^{1}$ \\ UNICENTRO - Universidade Estadual do Centro-Oeste
}

\begin{abstract}
RESUMO: O desenvolvimento do aluno, enquanto leitor competente, ainda é um objetivo a ser atingido no ensino, a contar pelos dados em avaliações realizadas no país, nas quais os estudantes ficam abaixo da média esperada. Diante deste contexto, nosso propósito, no texto em pauta, é apresentar uma proposta de aula de leitura, desenvolvida no período de doutoramento, cuja metodologia prioriza a produção de sentidos por parte do aprendiz. A teoria que embasa as discussões teóricas, bem como as atividades realizadas, é a Semiótica de linha francesa, proposta por A. J. Greimas. Para este trabalho, apresentamos um recorte das análises desenvolvidas acerca do texto "Metonímia, ou a vingança do enganado - drama em três quadros", de Rachel de Queiroz, priorizando o nível narrativo do percurso gerativo do sentido. As atividades elaboradas e, posteriormente, aplicadas em sala, versam sobre as questões apontadas durante a análise do texto, levando, desta forma, as contribuições do percurso gerativo do sentido para o contexto escolar. A partir das aulas ministradas, foi possível verificar que a Semiótica pode ser incorporada ao ensino, enquanto arcabouço teórico-metodológico, para o desenvolvimento de atividades que visam à produção de sentidos de diferentes textos. Cabe destacar, ainda, que faremos uma articulação entre a Semiótica e a metodologia de leitura denominada "Campos Lexicais", melhor descrita no corpo do trabalho.
\end{abstract}

PALAVRAS-CHAVE: Ensino; Leitura; Produção de sentidos; Semiótica.

ABSTRACT: The development of the student as a competent reader is still a goal to be achieved in teaching, taking into consideration the data obtained by evaluations that are conducted in the country, in which students are under the expected average. In this context, our purpose, the text on the agenda, is to present a proposal for reading classes, developed during the $\mathrm{PhD}$, whose methodology prioritizes the production of meaning by the learner. From the perspective of Semiotics from the French line, the theory highlighting the theoretical discussions as well as the activities is the one proposed by A. J. Greimas. Thus, for this work, we present an outline of the analysis conducted on the text "Metonímia, ou a vingança do enganado - drama em três quadros", (Metonymy, the revenge of the deceived - a three scene drama) by Rachel de Queiroz, pointing out the narrative level of the generative process of meaning. The activities developed and subsequently applied in the school context, deal with the issues raised during the examination of the text, leading, thus, the contributions of the generative process of meaning to the school context. Results after classes pointed out that Semiotics can be incorporated into

\footnotetext{
${ }^{1}$ Professora da Universidade Estadual do Centro-Oeste/UNICENTRO, departamento de Letras. Mestre (2003) e Doutora (2011) em Estudos da Linguagem pela Universidade Estadual de Londrina. Membro do Grupo de Pesquisa Língua \& Linguagens filiada à linha de pesquisa Língua, texto e ensino. Membro do Laboratório em Estudos Linguísticos e Literários (LABELL).
} 
teaching, while theoretical-methodological framework, for the development of activities aimed at the production of meanings in different texts. It is worth to highlight, though, that we will make a link between the Semiotics and the reading methodology called "Lexical Fields", which is best described in the present study.

KEYWORDS: Teaching; Reading; Meaning production; Semiotics.

\section{Introdução}

Apesar de avanços nos estudos linguísticos no país, e de tantas pesquisas/estudos discutirem a abordagem da leitura na escola, ainda é possível afirmar que o ensino não está cumprindo seu papel na formação de leitores competentes. Tal fato se confirma em avaliações realizadas no país cujo enfoque incide sobre leitura. Como exemplo, podemos citar os índices do PISA (Programa Internacional de Avaliação de alunos) que avalia, dentre outras áreas, o nível de leitura dos estudantes de diferentes países. Em 2000 o Brasil ficou em último lugar, com 396 pontos dentre os países avaliados. Com o índice obtido, o Brasil foi classificado no Nível 1 (entre 335 a 407), nessa escala os alunos são aqueles capazes, apenas, de localizar informações explícitas em um texto, de reconhecer o tema principal ou a proposta do autor, de construir uma conexão simples entre uma informação expressa em um texto de uso cotidiano e outras já conhecidas. Na última avaliação realizada pelo PISA, em 2009, o Brasil atingiu 412 pontos, mesmo assim o país continua muito abaixo dos países desenvolvidos, ocupando o $53^{\circ}$ lugar dentre os 65 que fizeram o exame.

Além desses dados, pudemos observar durante o período de doutoramento ${ }^{2}$ que o nível de leitura dos alunos ainda precisa de uma atenção especial. Constatamos, na ocasião, como os aprendizes têm dificuldades de lidar com a organização figurativa dos textos lidos. Por exemplo, depois de terem lido o texto "Circuito Fechado (1)", de Ricardo Ramos, e realizado as atividades de compreensão proposta pelo livro didático, os alunos não conseguiram resolver uma questão de inferência, a partir de figuras elencadas do texto lido. O exercício proposto, figura 01, intitulada "Jogo Rápido", tinha o propósito de, com base em elementos do texto, levantar hipóteses sobre a atividade profissional da personagem.

\footnotetext{
${ }^{2}$ A pesquisa, em questão, foi realizada em 2008 em uma turma de $8^{a}$ série de uma escola pública da região central do Paraná. Ver: Merith-Claras, Sonia. Semiótica, leitura, análise linguística: uma proposta de intervenção no ensino fundamental. 2011. 356f. Tese (doutorado em Estudos da Linguagem) - Universidade Estadual de Londrina, Londrina. In: http://www.uel.br/cch/ppgel/.
} 
JOGO Releia: "(...) Mesa e poltrona, cadeira, cinzeiro, papeis, telefone, agenda, copo com lápis, canetas, bloco RAPIDO/ de notas, espátula, pastas, caixas de entrada, de saída, vaso com plantas, quadros, papeis, cigarro, fósforo. Bandeja, xicara pequena. Cigarro e fósforo. Papéis, telefone, relatórios, cartas, notas, vales, cheques, memorandos, bilhetes, telefone, papéis. Relogio. Mesa, cavalete, cinzeiros, cadeiras, esboços de anúncios, fotos, cigarro, fósforo, bloco de papel, caneta, projetor de filmes, xícara, cartaz, lápis, cigarro, fósforo, quadro-negro, giz, papel,"

RAMOS, Ficardo Cincinto fechado / II. op. cit., D. 21 .

1. Com base na sequiencia que você releu, escreva para cada item uma resposta breve:

a. a provável atividade profissional da personagem:

b. o(s) ambiente(s) em que os fatos parecem ocorrer;

c. o período de tempo em que se dão os acontecimentos;

d. as açōes praticadas pela personagem.

2. Observe o inicio e o final de Circuito fechado (1).

"Chinelos, vaso, descarga. Pia, sabonete. Água. Escova, creme dental..."

"... Vaso, descarga; pia, água, escova, creme dental, espuma, água. Chinelos. Coberta. cama, travesseiro."

Na sua opinião, como será o próximo dia?

3. Na narrativa predominam substantivos. Que efeito(s) de sentido esse emprego poderia dar ao texto?

Figura 1 - Atividade Jogo Rápido

Fonte: BORGATTO, A.; BERTIN, T.; MARCHEZI, V. (2008, p.26.)

Ao serem questionados acerca da provável atividade profissional da personagem, os alunos ficaram confusos e mencionam profissões aleatórias, tais como: empresário; advogado; contador; cozinheiro; fazendeiro, professor... Em suma, os alunos não souberam se deter nas informações, nas pistas deixadas no texto a fim de levantar hipóteses e chegar à profissão da personagem. A realização da atividade, relatada acima, evidenciou como a abordagem do texto, da organização figurativa, precisa ser tratada de maneira menos superficial na escola.

Considerando este contexto, apresentamos uma proposta de aula de leitura, desenvolvida no período de doutoramento, a qual se utiliza da teoria Semiótica como suporte teórico-metodológico. A fim de possibilitar aos educandos um trabalho mais intenso, a respeito da organização figurativa do texto "Metonímia, ou a vingança do enganado - drama em três quadros"3, de Rachel de Queiroz, utilizamo-nos da metodologia de leitura intitulada "campos lexicais", a ser descrita neste trabalho.

Para dar conta de nosso objetivo, o artigo está dividido da seguinte maneira: apontamentos teóricos acerca da teoria semiótica; considerações sobre a metodologia de leitura utilizada "campos lexicais", bem como apresentação dos agrupamentos elaborados; e, por último, explanação da análise semiótica e atividades propostas.

\section{Teoria Semiótica: Breve Introdução}

\footnotetext{
${ }^{3} \mathrm{O}$ texto encontra-se anexado a este trabalho.
} 
A Semiótica, teoria desenvolvida por Algirdas Julien Greimas, tem na obra Semântica Estrutural seu marco inaugural. No Brasil, muitos autores vêm publicando trabalhos visando a divulgar o projeto semiótico, dentre esses, destacam-se Diana Barros e José L. Fiorin.

A Semiótica insere-se entre as teorias que concebem o texto, e não mais a frase, como unidade de sentido. Conforme Barros (2005, p.7), importa para a Semiótica "descrever e explicar o que o texto diz e como ele faz para dizer o que diz". O texto, no viés semiótico, deve ser entendido tanto como objeto de significação quanto de comunicação entre sujeitos.

A fim de explicar os sentidos dos textos, no que diz respeito ao plano do conteúdo, a Semiótica faz uso do percurso gerativo do sentido. Esse percurso é compreendido como "uma sucessão de patamares, cada um dos quais suscetível de receber uma descrição adequada, que mostra como se produz e se interpreta o sentido" (FIORIN, 2006, p.20), num processo que vai do mais simples e abstrato, ao mais complexo e concreto. A Semiótica utiliza-se do percurso gerativo para descrever os sentidos do texto, para tanto, trabalha com um nível fundamental, um nível narrativo e um nível discursivo. Esses níveis dão conta de explicar o sentido sendo que cada um desses níveis possui uma sintaxe e uma semântica.

O nível fundamental - também chamado de estruturas fundamentais - representa a primeira instância do percurso gerativo e procura explicar os níveis mais abstratos da produção, do funcionamento e da interpretação do discurso. Assim como os demais níveis do percurso gerativo do sentido, possui um componente sintático e um componente semântico. Nesse nível, uma categoria semântica fundamenta-se numa diferença, numa oposição. No entanto, para que dois termos possam ser apreendidos conjuntamente, é preciso que tenham algo em comum, para que então se estabeleça uma diferença. Assim, os termos opostos de uma categoria semântica mantêm entre si uma relação de contrariedade, pois conforme Fiorin (2006, p.22), "são contrários os termos que estão em relação de pressuposição recíproca". Os elementos de uma categoria semântica recebem a qualificação euforia versus disforia. $\mathrm{O}$ termo que receber a qualificação semântica, euforia, é considerado um valor positivo. Contrariamente, o termo que receber a qualificação semântica disforia é considerado um valor negativo.

Quanto à sintaxe do nível fundamental, esta abrange duas operações: a negação e a asserção, que aparecem concomitantemente na organização de um texto. Conforme Barros (2005), no nível fundamental as categorias de uma oposição semântica são determinadas pelas relações sensoriais do ser vivo com esses conteúdos e considerados atraentes ou eufóricos e repulsivos ou disfóricos. Esses mesmos elementos, estabelecidos numa relação de oposição semântica, são negados ou afirmados por operações de uma sintaxe elementar, passíveis de serem representados por meio do quadrado semiótico.

Quanto ao nível narrativo, a partir das propostas de Vladimir Propp, a Semiótica desenvolve seu modelo de organização da narrativa, e é nesse nível que os elementos das oposições semânticas fundamentais são assumidos como valores por um sujeito. As narrativas, conforme Barros (2005), têm uma organização canônica em que três percursos se relacionam por pressuposição: o percurso da manipulação, o percurso da ação e o da sanção, sendo que cada um deles é constituído por unidades elementares mais simples, os enunciados narrativos, organizados hierarquicamente.

Há dois tipos de enunciados narrativos elementares: enunciados de estado, em que sujeito e objeto mantêm entre si relações transitivas estáticas, uma relação de estar com um objeto (conjunção), ou uma relação de estar sem um objeto (disjunção); enunciados de transformação, em que a relação é dinâmica. É da organização de pelo menos um enunciado de estado e um enunciado de transformação que se estabelece o programa narrativo, a 
unidade funcional da narrativa. O esquema narrativo, percebido pelos percursos descritos a seguir, nos possibilita perceber as transformações da narrativa.

É no percurso da manipulação que um sujeito age sobre outro, a fim de levá-lo a querer e/ou dever fazer alguma coisa. O sujeito operador é denominado destinador e o sujeito de estado, sobre quem ele age é chamado destinatário. É na manipulação que aparecem as diferentes estratégias de persuasão do destinador sobre o destinatário, como a intimidação, a tentação, a sedução e a provocação.

No percurso da ação se organizam os programas narrativos de performance e competência. O programa da performance é a fase em que se dá a transformação central da narrativa. Nesse programa, o valor do objeto é um valor descritivo final, isto é, constitui o valor último a que visa o sujeito da narrativa, mas para que a transformação ocorra, é preciso que o sujeito transformador seja competente para tal, por isso, todo programa de performance pressupõe um programa de competência. Nessa fase da competência, de acordo com Barros (2005), o sujeito que vai realizar a transformação central da narrativa é dotado de um saber e/um poder fazer. Diferentemente do programa da performance, o objeto valor não é um valor descritivo, mas um valor modal e necessário para ser competente e realizar a transformação final.

O último percurso, a sanção, ocorre após a realização da performance. Ao realizar a performance da narrativa, o sujeito cumpre, de alguma maneira, sua parte no contrato/acordo assumido com o destinador-manipulador. Sendo assim, cabe ao destinador dar ao destinatário o reconhecimento pelo cumprimento, ou não, do acordo e, consequentemente, a retribuição ou a punição daí decorrentes. Para Fiorin, (2006, p. 31), "a narrativa pode pôr em ação um jogo de máscaras: segredos que devem ser desvelados, mentiras que precisam ser descobertas, etc. É na fase da sanção que ocorrem as descobertas e as revelações”.

A semântica do nível narrativo se ocupa dos valores inscritos nos objetos, que podem ser de dois tipos: os modais e os objetos de valor. Os primeiros são o querer, o dever, o saber e o poder fazer, e constituem elementos cuja aquisição é necessária para realizar a performance principal. Dessa maneira, um sujeito que quer ou deve fazer alguma coisa para obter um dado objeto de valor é um sujeito virtual; um sujeito que pode e sabe fazer alguma coisa para obter um dado objeto de valor é um sujeito atualizado; um sujeito que realiza o fazer e adquire, por conjunção, o objeto de valor em questão é um sujeito realizado. Quanto aos objetos de valor, são os objetos com que se entra em conjunção ou disjunção na performance principal.

Além da modalização do fazer, a semântica narrativa dá conta da modalização do ser, em que é analisada a modalização veridictória, ou seja, aquela que, consoante Barros (2005, p. 45) "determina a relação do sujeito com o objeto, dizendo-a verdadeira ou falsa, mentirosa ou secreta, e o da modalização do querer, dever, poder e saber, que incide especificamente sobre os valores investidos nos objetos.

O nível discursivo é o patamar mais superficial, mais próximo da manifestação textual. No entanto, as estruturas discursivas são mais complexas e, por isso, mais enriquecidas do que as estruturas narrativas e fundamentais. Nesse nível, a narrativa vai ser colocada no tempo e no espaço, quando os sujeitos, objetos, ou melhor, os actantes da narrativa se tornam atores do discurso. A análise discursiva opera sobre os mesmos elementos que a análise narrativa, mas retoma aspectos que não foram enfocados, como por exemplo, as projeções da enunciação no enunciado. Todavia, é na sintaxe discursiva que os esquemas narrativos são assumidos pelo sujeito da enunciação, que faz escolhas tanto de pessoa, quanto de tempo e espaço, transformando a narrativa em discurso. 
A enunciação é o ato de produção do discurso, isto é, uma instância pressuposta pelo enunciado que, por sua vez, é o resultado, o produto da enunciação. Para Benveniste (1989, p.82), a enunciação é o ato de colocar em funcionamento, por um ato individual, a própria língua; "é ato mesmo de produzir um enunciado, e não o texto de um enunciado, que é nosso objeto". Segundo o autor, "antes da enunciação, a língua não é senão possibilidade da língua. Depois da enunciação, a língua é efetuada em uma instância de discurso, que emana de um locutor, forma sonora que atinge um ouvinte e que suscita uma outra enunciação de retorno" (p.83).

Entretanto, o enunciado deve ser compreendido como o resultado/produto da enunciação, é a instância em que podem ser observadas as escolhas do enunciador, pois, conforme Fiorin (2006, p. 55), "ao realizar-se, ela deixa marcas no discurso que constrói”. É nas estruturas discursivas que a enunciação mais se manifesta e se revela, e "onde mais facilmente se apreendem os valores sobre os quais ou para os quais o texto foi construído" (BARROS, 2005, p.54).

De acordo com Benveniste (1989), a enunciação pode ser definida como a instância do $e u$, do aqui e do agora: o eu realiza o ato de dizer num determinado tempo e num espaço específico. O aqui é o espaço do $e u$, a partir do qual todos os espaços são ordenados (aí, lá,...); já o agora é o momento em que o eu toma a palavra, organizando toda a temporalidade linguística.

Essa projeção dos atores no discurso se dá a partir de dois mecanismos: a debreagem e a embreagem. Conforme Fiorin (1999), é o enunciador, o sujeito da enunciação, que faz uma série de escolhas - diretamente relacionadas aos efeitos de sentidos que se deseja produzir - para projetar os atores do discurso. "Estudar as projeções da enunciação é, por conseguinte, verificar quais são os procedimentos utilizados para constituir o discurso e quais efeitos de sentido fabricados pelos mecanismos escolhidos" (BARROS, 2005, p.54). Como toda vez que produz um enunciado o enunciador quer comunicar algo ao enunciatário, ele realiza, então, um fazer persuasivo, procurando fazer com que esse aceite o que ele diz. Já o enunciatário realiza um fazer interpretativo.

Quanto à semântica do nível discursivo, a tematização e a figurativização são os principais procedimentos. Quanto ao primeiro procedimento, a depreensão de temas, este consiste em tematizar um discurso formulando os valores de modo abstrato, organizando-os em percursos, conforme Barros (2005, p.68), "em outras palavras, os percursos são constituídos pela recorrência de traços semânticos ou semas, concebidos abstratamente". Já a figurativização é o procedimento que visa a recobrir os percursos temáticos abstratos, atribuindo-lhes traços de revestimento sensorial, ou seja, "tematização e figurativização são dois níveis de concretização do sentido. Todos os textos tematizam o nível narrativo e depois esse nível temático poderá ou não ser figurativizado" (FIORIN, 2006, p. 90).

No processo de figurativização dos textos, há o recurso da ancoragem, que relaciona o discurso a pessoas, datas e espaços, a fim de que o receptor os reconheça como reais ou existentes. Este procedimento semântico concretiza "os atores, os espaços e o tempo do discurso preenchendo-os com traços sensoriais que os 'iconizam', os fazem 'cópias da realidade'. Na verdade, fingem ser 'cópias da realidade', produzem tal ilusão" (BARROS, 2005, p.60). Tanto a ancoragem actancial, temporal e espacial (recurso da semântica discursiva), quanto a delegação de voz (recurso da sintaxe discursiva) são procedimentos que visam à obtenção da ilusão de referente ou de realidade.

Em suma, o percurso gerativo do sentido, descrito sucintamente acima, abrange três diferentes níveis, o fundamental, o narrativo e o discursivo. Tais níveis são independentes, o 
que possibilita, em uma análise, priorizar apenas um deles para discutir os possíveis sentidos do texto/objeto analisado. No trabalho em pauta, abordaremos apenas o nível narrativo.

\section{Campos Lexicais: uma estratégia de segmentação}

Os campos lexicais, proposta metodológica desenvolvida por Maurand (1992), divulgada no Brasil por Limoli (1997, 2001, 2005), consistem no agrupamento de um conjunto de lexemas de um texto, desde que nesse grupo haja pelo menos um traço, um sema comum. "Esse mesmo traço mínimo de significação, ou sema, deve servir de denominação ou hiperônimo para o conjunto, cujos elementos serão chamados de hipônimos" (LIMOLI, 1997, p.25). De acordo com a autora, na montagem dos campos lexicais, além da hiperonímia, há outra relação de sentido que contribui para a complementaridade da significação global do texto, a polissemia. Isso quer dizer que uma mesma palavra pode figurar em dois campos lexicais diferentes, em função do caráter, das características polissêmicas que as palavras possuem.

A segmentação, a montagem do campo lexical pode ser iniciada, em qualquer texto, com hiperônimos mais recorrentes, como: a) tempo, espaço, atores; b) categoria sensorial: gustativo, visual, auditivo, tátil; c) vida versus morte; d) alegria versus tristeza. Apesar de alguns agrupamentos serem mais prováveis nos textos, como os citados acima, é o texto que vai direcionar os campos lexicais possíveis. Conforme Limoli (1997, p.36), "a decomposição do texto-objeto em campos lexicais é o primeiro passo para a exploração dos componentes do texto". A montagem dos campos lexicais é um instrumento auxiliar de análise, cujo objetivo não se situa no léxico, mas nas relações semânticas entre os diferentes sememas presentes no discurso. Ao percorrer o texto, a fim de montar os campos lexicais, o analista executa uma varredura nesse texto, o que propicia uma prática de releitura. Esse contato com a organização discursiva do texto, ou melhor, essa prática metodológica de reconstruir a figurativização de um objeto de análise, encaminha o analista para dentro desse texto. Isso faz com que ele trabalhe com a materialidade, a concretude textual, percebendo que os sentidos se constroem a partir dessa figurativização.

Considerando tais questões, realizamos a segmentação do texto "Metonímia, ou a vingança do enganado - drama em três quadros", para só depois empreender a análise semiótica. Em sala de aula realizamos este mesmo procedimento, isto é, primeiro os alunos levantaram figuras, conforme os agrupamentos sugeridos por nós, descritos na sequência, para depois realizar as atividades de leitura. A montagem dos campos, quadro I e II, foi feita em conjunto, isto é, por nós e pelos alunos. A abordagem em sala também respeitou a divisão do texto - quadro I, quadro II e quadro III. Convém destacar que além desta divisão, em três quadros, é possível reconhecer dois gêneros textuais distintos, ou seja, o texto se inicia com uma crônica e, no interior desta, há o desenvolvimento de um conto. Neste trabalho, por questões de espaço, abordaremos apenas o conto inserido nos quadros I, II e III.

\section{Campos Lexicais: dos agrupamentos sugeridos - quadro I}

Maurand (1992, apud LIMOLI, 1997) sugere que após a organização, o levantamento dos campos lexicais, seja elaborada uma justificativa dos diferentes campos e de sua composição. Essa justificativa tem, entre outros objetivos, o de explicitar a escolha e a classificação de alguns lexemas, principalmente nos casos em que a seleção não se justifique fora do contexto analítico. Ao proceder esta justificativa, estamos elencando, também, os agrupamentos elaborados por nós e posteriormente utilizados nas atividades em sala de aula. 
Conforme Limoli (1997) os campos da espacialidade, temporalidade e actorialidade estão sempre presentes na organização discursiva de qualquer texto, por isso é pertinente começar a discussão por tais agrupamentos. A fim de melhor compreender o levantamento dos campos lexicais, sugere-se a leitura do conto, quadro I, II e III, anexado a este artigo.

Os lexemas descritos no hiperônimo da actorialidade marcam uma indeterminação, uma não referência a nomes dos sujeitos da narrativa. O narrador opta por não especificar tais sujeitos, daí os hipônimos "um homem", "a moça", "o marido", "ela", "um sargento". Essa escolha pela generalidade, e não pela especificidade, dá-se, também, em relação à ancoragem da espacialidade, haja vista que os lexemas escolhidos visam a não identificação de um local, um espaço específico onde os fatos se deram, "numa cidade do interior", "Ceará", "São Paulo", "Pernambuco", "Pará". Os lexemas, que marcam um espaço geográfico, visam a despistar o leitor, confundi-lo sobre um local em específico, tanto que o próprio narrador diz ser essa sua intenção. Em relação à hiperonímia temporalidade, os hipônimos que ancoram, marcam o tempo também apontam para a generalidade "em moço", "para sempre", "antes do tempo". A forma como o enunciador ancora os fatos no que diz respeito à actorialidade, espacialidade e temporalidade reitera a ideia da indeterminação, uma vez que não há uma ancoragem de nome dos sujeitos, nem de data e, ainda, de espaço. No caso da espacialidade, há ancoragem, uma referência a diferentes Estados, o que corrobora com a não identificação.

Quanto ao enquadramento sensorial, há três hiperônimos visual, gustativo e tátil recorrentes no texto, sendo que o campo gustativo traz um número bem maior de hipônimos, "boa nutrição", "boa carne fresca", "o seu bom tutu", "carne", "os doces de lata", "comer bem". Esse campo aponta para uma transformação da narrativa, a mulher, que antes não desfrutava de boa alimentação, depois de casada, passa a viver em conjunção de uma boa alimentação. É essa boa alimentação que resultará numa transformação física desse sujeito, já que passará de cara-de-tísica à moça bela e formosa. Já o campo visual traz hipônimos que demonstram a aparência física do homem, "cor terrosa", "olhar vidrado", "amarelo". Diferentemente desses dois campos, o tátil traz apenas uma figura, "morna", o que demonstra que, nesse primeiro quadro, as transformações estão relacionadas ao visual e ao gustativo.

Relacionado, ainda, ao campo gustativo está o campo da posse. É possível observar, a partir dos hipônimos da posse, figuras que apontam para um sujeito homem em conjunção com a riqueza, "mercearia", "comércio", "comprava aos centos", "em casa sua", "afluência do dinheiro". Com o casamento, a mulher também entra em conjunção com a riqueza, por isso passa a comer bem, o que justifica tantos lexemas no campo gustativo. Os hipônimos do campo da privação, "pobre", "operária", "trabalho", "não tinha nada", apontam para o estado da mulher antes da transformação da narrativa, ou seja, antes do casamento quando ela ainda não estava em conjunção com a riqueza.

Assim como os campos gustativo e posses relacionam-se, outros agrupamentos têm relação com tais hiperônimos, como o campo lexical transformação e, ainda, belo versus feio. Como dito acima, depois de casada a mulher entra em conjunção com a riqueza, como reiteram as figuras do campo das posses. Nessa nova condição, a mulher passa a se alimentar bem, como justificam as figuras do campo gustativo, e isso a leva a transformar-se em uma mulher mais bonita "mudou como se fosse encantada", "começou a botar corpo", "estava crescendo", "aumentar os dotes naturais", entre outros lexemas do campo transformação. Essa mudança física faz com que a mulher saia de condição de "magrinha", "cara de tísica" e "feia" passando a moça bonita, "assim bela", "assim vestida", "nada de feia", "assim pintada e formosa", como observado no campo belo versus feio. Esse último hiperônimo, feio, também traz figuras que caracterizam o homem, "corpo franzino", "amarelo" e "mal ajambrado". 
As figuras do campo transformação apontam para outro campo, a intensidade. Esses campos não se contrapõem, apenas evidenciam que as mudanças no aspecto físico do sujeito mulher foram intensas, "assim bela", "assim vestida", "assim pintada e formosa". O campo intensidade se relaciona, também, com o campo belo versus feio, afinal, o marido não era apenas um homem feio, mal-ajambrado, mas sim, "tão mal-ajambrado", "pior que velho".

Outro campo lexical pertinente à compreensão do texto diz respeito aos hiperônimos vivacidade versus decadência. Desse campo lexical convém destacar o hiperônimo decadência. Esse traz um rol de lexemas relacionados à saúde, ao bem estar do marido, "pernas fracas", "o peito cansado", "asmático", "doente crônico", "envelhecido antes do tempo", "corpo franzino", "amarelo". Essas figuras reiteram que a mulher se casa com um homem de posses, no entanto, um homem envelhecido antes do tempo, com aspecto decadente. Ela, que também era magrinha e tinha cara-de-tísica, passa a conviver no conforto, a comer bem, daí ter-se transformado numa mulher mais bela, enquanto o marido permanece em seu estado inicial, ou seja, feio e decadente.

No hiperônimo lazer há hipônimos que dizem respeito às ações, descontrações, ao lazer propriamente dito, oferecido à esposa pelo marido, "sentava na cadeira preguiçosa", "por amor não se interessava", "convivência morna", "insossa", "ité". Na narrativa, é essa falta de lazer, apenas uma convivência morna, sem afetos, carinhos, amor, que vai alterar a competência modal da esposa, ou seja, ela passa a querer desfrutar de uma vida não propiciada pelo marido.

Além desses campos, comentados acima, outros foram levantados, no entanto, optamos por discutir apenas os agrupamentos utilizados na elaboração das atividades.

\section{Campos Lexicais: dos agrupamentos sugeridos - quadro II}

O enquadramento situacional, assim como no quadro I, continua apontando para a generalidade. No campo da actorialidade, não há hipônimos que apontem para alguém, em particular, apenas "marido", "esposa", "sargento", "moça", "menino". Não há, também, lexemas que digam respeito a espaços específicos, que remontem à espacialidade, pelo contrário, os hipônimos "no balcão", "na tampa", "no quarto", "ali", "aqui" não especificam uma cidade, um lugar dos acontecimentos. Quanto ao tempo, diferente do quadro I, os lexemas relacionados ao hiperônimo temporalidade são bem mais recorrentes, além disso, os hipônimos indicam continuidade, duratividade dos acontecimentos, "durante o sono", "durante cinco meses", "diariamente", "todos os dias", "sempre", "já". As figuras, relacionadas à temporalidade têm uma ligação com as investigações e descobertas do marido a respeito da traição da esposa.

O agrupamento sensorial também sofre alterações, se comparado com o quadro I. O hiperônimo gustativo, por exemplo, traz hipônimos que dizem respeito ao sujeito homem, à sua aflição, quando das descobertas da traição "cuidava de comer", "engolia depressa", "uma colher de caldo", "roía um pedaço de pão", "atravessado na garganta". O hiperônimo auditivo, agrupamento não recorrente no quadro I, mas que tem muitas figuras no quadro II, "disse alguma palavra", "a lhe escutar", "os silêncios", "os suspiros e os murmúrios", "suspiros, silêncios e murmúrios", "não a ouviu", "basta que se diga" relaciona-se, também, a outro agrupamento, o campo do segredo. Ainda a respeito do enquadramento situacional, os lexemas do hiperônimo visual, que no quadro I diziam respeito ao aspecto visual do sujeito homem, no quadro II trazem figuras relacionadas ao desmascaramento da esposa, ao despertar das suspeitas do marido a partir da aparência da mulher, "incharam", "por sob o rouge", "cara-de-tísica". 
O hiperônimo segredo traz um rol de lexemas, de figuras relacionadas aos mistérios, ao relacionamento secreto da mulher com o sargento, e, também, às descobertas do marido, desse relacionamento, "o que houve", "o que não houve", "murmurada tão baixo", "como se encontravam", "onde", "as cartas de amor", "não acordadas", "guardava tudo". Relacionado ao hiperônimo segredo está o agrupamento traição, este que traz figuras que apontam para o envolvimento da mulher com o sargento "a moça consentiu", "se amaram de amor proibido", "despertar as suspeitas do marido", "aquele amor de dois ladrões".

No quadro I, o hiperônimo intensidade está relacionado à beleza da esposa, já no quadro II, essa intensidade se refere aos novos fatos que envolvem os sujeitos, ou seja, a intensidade da tristeza da esposa quando da transferência do sargento, "tanto choro", "assim alardeado"; às descobertas do marido, "fatal", "à maior de todas", "tantas descobertas pequenas"; e ao namoro entre a mulher e o sargento, "pegara firme", "muito além".

Quanto ao campo belo versus feio, o primeiro hiperônimo é bem recorrente no quadro II, este traz figuras que descrevem o novo sujeito da narrativa, o sargento, "era simpático", "era musculoso", "era formidavelmente marcial", "andar elástico". Já o hiperônimo feio traz figuras relacionadas à aparência física da mulher, após a transferência do sargento, "incharam", "cara-de-tísica".

Diferente do quadro I, o agrupamento vivacidade versus decadência, além de não trazer tantas figuras, estas não se referem, propriamente, às características dos sujeitos, mas às mudanças de estados da narrativa, "nova situação", "amor florescia", "progresso do choco", "a nova".

Como é na segunda parte do conto que ocorre o envolvimento do sargento com a mulher, é nesse quadro que há reiteradas figuras apontando para o hiperônimo relacionamento. Estas não dizem respeito somente ao relacionamento do casal, mas são figuras que reiteram a ideia de envolvimento secreto: "o casal", "o namoro", "se amaram", "amor proibido", "Tristão e Isolda", "Paolo e Francesca", "amores ilegais", "Diálogo de filme francês". Como esse relacionamento secreto é descoberto pelo marido, há várias figuras, no agrupamento revelação, que concretizam as descobertas do marido, "a vigiar", "a lhe examinar", "a lhe escutar", "acabou descobrindo", "a vigiar escondido", "descobriu um escudo". Ainda em relação às descobertas do marido está o campo correspondência cujas figuras "um postal", "as cartas de amor", "a carta nova", "reler a velha", "uma datada de 21 de agosto" concretizam as provas da traição. É nesse contexto de descobertas que a mulher, a qual parecia ser fiel, é desmascarada pelo marido, passando a mentirosa.

Outro campo lexical que não aparece no quadro I, mas que é pertinente no quadro II, é o enquadramento dos sentimentos. Isso porque, mesmo com o casamento do homem e da mulher, quadro I, não há figuras relacionadas aos sentimentos dos sujeitos. É a partir do relacionamento da mulher com o sargento que figuras relacionadas à alegria, aos sentimentos, eufóricos, "rindo", "amor florescia", "eram rosas", "lua-de-mel" aparecem. Com o rompimento desse mesmo relacionamento os sentimentos de tristeza, disfóricos, manifestamse, "conhece a dor da separação", "pranto e fastio", "tanto choro".

Priorizamos, assim como fizemos nos comentários dos agrupamentos do quadro I, apenas os campos lexicais utilizados na elaboração das atividades para os alunos.

\section{Campos Lexicais: dos agrupamentos sugeridos - quadro III}

É no quadro III, enquanto organização da narrativa, que ocorre o último percurso, a sanção. Assim, as figuras dos agrupamentos estão relacionadas à ação do marido, enquanto destinador-julgador, que após julgar a ação da esposa vai sancioná-la pelo cumprimento, ou 
não, do contrato estabelecido. Dessa forma, as figuras dos campos lexicais do texto apontam para essa última ação. Quanto ao enquadramento situacional, o hiperônimo temporalidade traz hipônimos que apontam para um tempo, um momento específico, "um dia", "numa manhã", "eram dez horas em ponto", "daí a pouco". Quanto à espacialidade, há figuras relacionadas a um espaço que envolve o armazém, a casa e a rua, ambientes onde se dá a última transformação do conto: "o armazém", "da loja", "a sua casa", "a porta da frente", "da casa de moradia", "a esquina", "na calçada". Quanto à actorialidade, como nos demais quadros, não há nomes, apenas figuras genéricas, sem referência a uma pessoa em particular: "ele", "um devedor", "o bodegueiro", "aos presentes", "a freguesia", "mulher", "o próprio marido". Não há, no quadro da actorialidade, o hipônimo sargento, como nos demais quadros.

No enquadramento sensorial, há somente dois hiperônimos, o visual e o auditivo. A primeira figura do campo lexical visual, "sol claro", aponta para a descoberta, a revelação, o desfecho. Nada mais ficará escondido. As demais figuras desse agrupamento trazem, também, a caracterização do homem, mais precisamente, do homem assassinado pelo marido "só as botinas pretas", "vestidas em calças cáqui". O campo auditivo, bem mais recorrente no quadro II, quando das descobertas, no quadro III traz hipônimos que dizem respeito à ação do marido "um ruído de altercação", "um grito de mulher", "explosões secas", "aos gritos".

O campo do segredo não diz respeito aos encontros, ao envolvimento da mulher com o sargento, mas ao sujeito da narrativa assassinado pelo marido, "não se lhe via", "nem cara nem torso", "isso não se explicou". Em relação ao campo da intensidade, este diz respeito ao limite suportado pelo marido traído, "provocação maior", "saturou-se", "até ao ponto de".

Em relação aos sentimentos eufóricos e disfóricos, não há qualquer referência à euforia, há apenas lexemas que apontam para sentimentos disfóricos, como "provocação maior", "ódio", "ciúme", "apavorado", "muito trêmulo", "aos gritos".

Em razão da ação que ocorre nesta parte do conto, quadro III, que diz respeito à sanção, os hiperônimos movimento e estaticidade são extremamente recorrentes. Há, na ação do marido, todo um movimento de preparação à ação final: "carregou a arma", "transpunha a porta de comunicação", "cortaram o ar" "tentando soerguê-la", "andou um passo". Já a estaticidade traz figuras referentes ao resultado da ação do marido, ou seja, à morte de um homem, "estava armada", "atravessado na porta", "caído de borco", "na posição em que estava", "jazia", "o morto".

Assim como não há figuras relacionadas a sentimentos eufóricos, não há, também, figuras relacionadas à vida, unicamente à morte, "um revólver", "caixa de balas", "um ruído de altercação", "três tiros", "explosões secas", "a tragédia", “jazia”, “o morto".

A partir dos comentários dos principais campos lexicais, tanto do quadro I, quanto do quadro II e III, foi possível observar a predominância de alguns agrupamentos conforme aconteciam as transformações da narrativa. O quadro I, quando da caracterização dos sujeitos homem e mulher, os campos da posse versus privação são fortemente marcados. Além desses, os hiperônimos belo versus feio e vivacidade versus decadência também trazem lexemas que caracterizam os estados dos sujeitos na narrativa. Esses estados sofrem mudanças, como apontam as figuras do agrupamento transformação, que por sua vez têm relação com o hiperônimo gustativo. É interessante salientar que mesmo se tratando de um único texto, um conto, de acordo com as transformações, as mudanças de estados novos agrupamentos vão surgindo, enquanto outros deixam de ter figuras recorrentes. Isso é possível de se comprovar observando os campos do quadro II, que já não trazem tantas figuras no campo da posse versus privação, mas que têm novos campos segredo, relacionamento, traição, revelação e sentimentos, tanto eufóricos quanto disfóricos, não mencionados no 
quadro I. Isso porque é no quadro II que a mulher passa a se relacionar com o sargento. É nesse mesmo quadro que o sujeito marido descobre a traição, daí as figuras da revelação, dos sentimentos disfóricos e mesmo a reincidência de figuras no campo do auditivo. Já no quadro III, o campo vida versus morte aparece. É nesse quadro que o sujeito marido sanciona a esposa, como é o momento da ação o campo movimento versus estaticidade tem figuras incidentes. Os agrupamentos do campo III ainda dizem respeito aos sentimentos disfóricos, mas já não há uma recorrência de figuras relacionadas à euforia.

Acreditamos não ser suficiente no processo de leitura, o aluno, enquanto leitor, percorrer os caminhos do sentido de forma superficial, é preciso adentrar ao texto, fragmentálo, para só depois construir, abstrair o sentido do todo. Durante a montagem dos campos lexicais, o aluno tem a possibilidade de discutir possibilidades, refletir sobre o sentido das partes para entender as relações que as figuras têm no texto. Pode, ainda, compreender que as escolhas discursivas, feitas pelo enunciador, não são aleatórias.

A seguir, apresentamos as análises empreendidas acerca do conto, quadro I, II, III e, em meio às análises, arrolamos os exercícios desenvolvidos com os alunos. Para este artigo, por uma questão de espaço, priorizamos apenas o trabalho desenvolvido acerca do nível narrativo, o qual nos subsidiou na elaboração das atividades de leitura.

\section{Análise Semiótica e Atividades Desenvolvidas: o Conto no Viés da Sintaxe e da Semântica Narrativa - QUADRO I}

Na perspectiva do nível narrativo, do percurso gerativo do sentido, o conto traz um

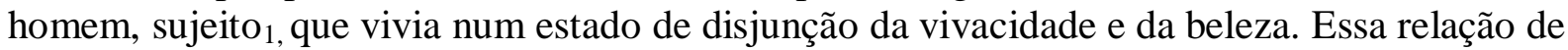
disjunção, entre sujeito e objeto-valor, diz respeito à beribéri, doença tida pelo homem quando ainda era moço, o que lhe arruinou para sempre o futuro. A ausência de vivacidade está reiterada nas figuras pernas fracas, o peito cansado e asmático, a cor terrosa, o olhar vidrado de doente crônico. Por isso, mesmo não sendo um homem velho, era pior que velho, porque era gasto. Esse aspecto decadente o colocava numa relação de disjunção da vivacidade e, consequentemente, da beleza.

$$
\mathrm{S}_{1}(\text { homem }) \cup \mathrm{O}_{\mathrm{v}}(\text { vivacidade, beleza }) \text {. }
$$

Esse mesmo sujeito, que tem uma relação de disjunção com a vivacidade e a beleza, vive em conjunção com a riqueza, pois era homem de algumas posses, possuía casa própria com loja contígua, onde instalara o armazém, e quem tem comércio tem dinheiro.

$$
\mathrm{S}_{1}(\text { homem }) \cap \mathrm{O}_{\mathrm{v}} \text { (riqueza) }
$$

Como no decorrer do texto o homem, sujeito ${ }_{1}$, casa-se, é possível inferir outro enunciado de estado, uma relação de disjunção desse sujeito com uma companheira, uma esposa:

$\mathrm{S}_{1}($ homem $) \cup \mathrm{O}_{\mathrm{v}}($ companheira $)$.

Para dar conta dessas questões, propusemos, em sala, o seguinte exercício:

1 - Após a montagem dos campos lexicais, responda: 
a) Com base no primeiro campo lexical, o "enquadramento situacional", quais são os personagens do texto, ou melhor, do conto? Onde se dão os fatos?

b) A partir dos campos lexicais "vivacidade x decadência" e "belo x feio", caracterize o sujeito homem.

O casamento desse homem, sujeito ${ }_{1}$, é a primeira transformação da narrativa. No entanto, para que fosse possível a realização do casamento, era necessário, além do homem, um outro sujeito, uma mulher pré-disposta a casar-se com ele. Essa mulher, entretanto, não poderia ser qualquer uma, pois deveria ser alguém que se interessasse por um homem, que, apesar de estar em conjunção com a riqueza, vivia disjunto da vivacidade e beleza.

A mulher, escolhida pelo homem para ser manipulada a querer casar-se com ele, era moça pobre, magrinha, operária numa oficina de roupas de homem. Como trabalhava de operária numa fábrica de roupas de homem, vivia em disjunção da riqueza, do conforto e, por isso mesmo, tinha um aspecto mal cuidado, de mal alimentada. A condição de vida, a falta das posses e de uma boa alimentação a colocavam num estado de disjunção da beleza, daí sua aparência estar figurativizada como mulher magrinha, com cara de tísica, ou ainda, como nenhuma beldade.
a)
$\mathrm{S}_{2}($ mulher $) \cup \mathrm{O}_{\mathrm{v}}$ (riqueza);
b) $\mathrm{S}_{2}$ (mulher) $\cup \mathrm{O}_{\mathrm{v}}$ (beleza).

A partir do perfil da moça, a quem o homem procura para se casar, é possível pressupor que o homem, no papel actancial de destinador-manipulador, manipula a moça, no papel actancial de destinatário, por tentação. Ou seja, como não era jovem, saudável e belo, o que ele tem a oferecer a uma companheira é uma vida em conforto financeiro, cujas posses poderiam proporcionar. Interessante destacar que o destinador-manipulador, consciente do que tem a oferecer ao destinatário, não procura por moça bela, rica, mas sim, por moça pobre, magrinha a qual ele julga poder se interessar pelo que tem a oferecer, ou seja, suas posses. Cabe à mulher, no papel de destinatário, analisar e julgar a proposta do destinadormanipulador; e, como a moça se casa, fica explícito que lhe interessava esse marido.

O sucesso da manipulação aponta para as modalizações que tornaram a mulher, no papel de destinatário, competentes para realizar a performance. Ela que já podia, pois era solteira, com a manipulação passa a querer se casar. Como pode e quer, ela é competente para realizar a performance. O casamento concretiza o percurso da ação.

Com o casamento o sujeito ${ }_{1}$ e o sujeito ${ }_{2}$ têm seus estados iniciais, de disjunção de um cônjuge, alterados. Tanto para o homem quanto para a mulher a transformação é de aquisição ou, ainda, de liquidação da privação. Sendo assim, o homem, sujeito ${ }_{1}$, e a mulher, sujeito $_{2}$, são sujeitos realizados, pois ao realizarem um fazer, adquirem, por conjunção, o objeto-valor.

$$
\begin{aligned}
& \mathrm{PN}_{1} \\
& \mathrm{~F}:\left(\text { casar-se) } \left[\mathrm{S}_{1} \text { (homem) } \rightarrow \mathrm{S}_{2} \text { (mulher) } \cap \mathrm{O}_{\mathrm{v}}\right.\right. \text { (cônjuge/companheiro)] } \\
& \mathrm{F}:\left(\text { casar-se) } \left[\mathrm{S}_{2} \text { (mulher) } \rightarrow \mathrm{S}_{1} \text { (homem) } \cap \mathrm{O}_{\mathrm{v}}\right.\right. \text { (cônjuge/companheira)] }
\end{aligned}
$$

Essa transformação da narrativa acarretará, ainda, em outras mudanças de estados. A mulher, que antes do casamento era operária e que vivia numa relação disjunta da riqueza e do conforto, depois de casada passa a desfrutar dos bens do marido, com isso, entra em conjunção com a riqueza. Ou seja, agora, em sua casa, deixa a vida de operária e passa a comer bem, a viver no conforto, como indicam as figuras: a boa carne fresca, o seu bom tutu, 
a sua salada de pepino, os doces de lata, as doces laranjas da serra que o marido comprava aos cento para a freguesia.

$$
\mathrm{S}_{2} \text { (mulher) } \cap \mathrm{O}_{\mathrm{v}} \text { (riqueza). }
$$

Além dessa mudança de estado há outra, pois a boa alimentação e o novo estilo de vida causam alterações na aparência física da mulher, tanto que ela mudou como se tivesse sido encantada. Começou a botar corpo, a aumentar as polegadas nos lugares certos - parece até que estava crescendo. Além da boa alimentação propiciar uma mudança física, a mulher, com a afluência do dinheiro, deu para se vestir bem, se pintar, ondular o cabelo, usar engenho e arte a fim de aumentar os dotes naturais, o que a colocou numa relação de conjunção com a beleza.

$$
\mathrm{S}_{2} \text { (mulher) } \cap \mathrm{O}_{\mathrm{v}} \text { (beleza). }
$$

Em relação a tais questões, os alunos realizaram os seguintes exercícios:

2 - Considerando os campos lexicais "vivacidade x decadência" e "belo x feio", descreva o sujeito, mulher, antes do casamento.

3 - Um dos campos lexicais se refere à "posse x privação". Com base nesse campo lexical, responda:

a) Como era a situação financeira do homem?

b) Antes do casamento, como era a situação financeira da mulher?

c) Em relação às posses, o que muda na vida da mulher depois de casada?

4) Em relação à transformação da narrativa, ou seja, o casamento, responda:

a) Por que o homem deve ter procurado moça pobre, operária para se casar?

b) Como o homem deve ter manipulado, levado a moça a querer casar-se com ele?

5) Considerando o campo lexical "gustativo", como fica a alimentação da esposa depois do casamento?

6) Qual a possível relação entre os campos lexicais "gustativo", "transformação" e "belo x feio" no que diz respeito ao percurso da mulher no texto?

7) O campo lexical "intensidade" traz figuras, hipônimos, ou seja, palavras que evidenciam uma mudança física. Quem muda fisicamente depois do casamento, o homem ou a mulher?

Em relação ao sujeito $_{1}$, após o casamento, o homem tem apenas o seu estado de disjunção de uma companheira alterado, os demais estados permanecem os mesmos. Todavia, com o matrimônio, a mulher tem todos os seus estados iniciais, de disjunção, alterados para uma relação de conjunção, ou seja, a mulher, ao entrar em conjunção com um companheiro, consequentemente, entra em conjunção com a riqueza desse companheiro, e de posse dessa riqueza, entra em conjunção com a beleza.

Apesar de estar recebendo do destinador-manipulador, o esposo, as recompensas oferecidas no programa de manipulação, a mulher começa a demonstrar uma insatisfação em relação ao cônjuge, mais precisamente, ao tipo de convivência propiciada pelo seu marido. Pois, além das posses, do conforto e da boa alimentação, a única coisa que o homem proporcionava à esposa era uma convivência morna, insossa, ité. Era um marido com restrições alimentares e que não tinha atividades de lazer, não se interessava por cinema, rádio e nem por futebol. Além do desinteresse por atividades de lazer, ele também não se 
interessava por amor. O próprio porte físico do marido, corpo franzino, amarelo não era de pedir amores, ou melhor, não despertava na esposa desejos amorosos. Não há afetividade no casamento, o marido oferece à esposa apenas o objeto-valor, riqueza, figurativizada pelo conforto, boa alimentação.

A insatisfação da esposa com essa convivência sem lazer, sem um relacionamento íntimo e afetivo, demonstra que a mulher buscava outro objeto-valor no casamento, não proporcionado até então pelo marido, por isso começou a lhe pesar o marido enfermiço, envelhecido antes do tempo. É nesse contexto que suscita um sargento. Seguem as atividades de compreensão acerca de tais discussões:

8) Com o casamento, quais mudanças ocorrem na vida da mulher e do marido?

9) O campo lexical "lazer" diz respeito às atividades dos momentos livres do casal. O que o marido proporcionava à esposa em termos de lazer? Como era a convivência dos dois?

10) A mulher, pela convivência, pela relação que tinha estabelecido com o marido, parece feliz?

11) O narrador afirma, no texto, que a mulher, depois de bela e formosa, começou a sentir o peso do marido enfermiço. Na sequência ele diz que suscitou um sargento. $\mathrm{O}$ que você acha que vai acontecer?

Como descrito anteriormente, a análise semiótica norteou todas as discussões de compreensão do texto. Quanto aos campos lexicais, estes auxiliaram no processo de abordagem e segmentação da organização figurativa do texto.

\section{Análise Semiótica e Atividades Desenvolvidas: o Conto no Viés da Sintaxe e da Semântica Narrativa - QUADRO II}

$\mathrm{O}$ sargento, sujeito $_{3}$, que suscita ainda no quadro I, apresenta um porte físico relativamente avantajado, em comparação ao aspecto físico do marido, sujeito ${ }_{1}$, pois além de simpático, era musculoso, era jovem, era formidavelmente marcial dentro da farda justa ao peito, o andar elástico, a fala ríspida habituada ao comando. A partir dessas figuras, é possível depreender que o sargento desfruta de uma relação de conjunção da beleza, da vivacidade, enquanto o marido, com seu aspecto decadente, corpo franzino de doente crônico vive numa relação de disjunção desse objeto-valor. O marido, apesar de disjunto da beleza e vivacidade, continua a manter, no quadro II, uma relação de conjunção com o objeto-valor, a riqueza. Em relação ao sargento, nada é mencionado, pelo narrador, a respeito de bens materiais que pudessem figurativizar a riqueza do militar.

$$
\begin{aligned}
& \mathrm{S}_{1}(\text { homem } / \text { marido }) \cup \mathrm{O}_{\mathrm{v}}(\text { vivacidade, beleza }) \cap \mathrm{O}_{\mathrm{v}}(\text { riqueza }) \\
& \mathrm{S}_{3}(\text { sargento }) \cap \mathrm{O}_{\mathrm{v}}(\text { vivacidade, beleza })
\end{aligned}
$$

Além dos sujeitos, sargento e marido, outro sujeito, a esposa, faz parte do quadro II. A esposa, ainda no quadro I, manifesta uma relação de insatisfação em relação à sua convivência com o marido, este que não se interessava por lazer, por afetos, por amor. Esse estilo de convivência, morna, coloca a esposa em disjunção da afetividade, da virilidade masculina, objeto-valor não proporcionado pelo marido. 
$\mathrm{S}_{2}$ (mulher/esposa) $\cap \mathrm{O}_{\mathrm{v}} \quad$ (beleza) $\cap \quad \mathrm{O}_{\mathrm{v}} \quad$ (riqueza) $\cup \quad \mathrm{O}_{\mathrm{v}}$ (vivacidade/beleza/virilidade masculina)

O envolvimento, o relacionamento da mulher e do sargento, já que com três almoços o namoro pegara firme, corresponde à segunda transformação da narrativa.

$\mathrm{PN}_{2}$

F: (arrumar um amante) $\left[\begin{array}{llllll}\mathrm{S}_{3} & \text { (sargento) } \rightarrow & \mathrm{S}_{2} & \text { (mulher) } \cap & \mathrm{O}_{\mathrm{v}}\end{array}\right.$ (vivacidade/beleza/virilidade masculina)]

Conforme o narrador, a esposa, ao se achar mais bela e mais formosa, o marido enfermiço, que nem por amores se interessava, começa a lhe pesar. Possivelmente a luxúria, destinador-manipulador, manipula a mulher, no papel actancial de destinatário, a querer desfrutar da juventude, da beleza e virilidade masculina, características não apresentadas pelo marido. A partir desse processo de manipulação, a esposa apresenta uma mudança em relação ao seu querer. Ela, que antes não manifestava interesse por afetos masculinos, começa a demonstrar um querer, mudança essa figurativizada por começou a lhe pesar o marido enfermiço. Mesmo aceitando a manipulação proposta, a mulher não tem a competência necessária para realizar a performance, isso porque, apesar de querer, ela não deve, pois é uma mulher casada e o envolvimento dela com outro homem, para desfrutar do objeto-valor, beleza e virilidade masculina, configuraria em rompimento do contrato estabelecido com este marido, quando do casamento.

Essa mudança, essa manifestação de um querer se dá ainda no quadro I. É nesse contexto, de uma mulher modalizada por um querer que suscita o sargento, homem vivaz, belo e forte. Esse sargento, no papel actancial de destinador-manipulador, começa a manipular a mulher, no papel de destinatário, por tentação, a querer envolver-se com ele. Essa manipulação não está explícita no texto, já que o próprio narrador afirma ser difícil reconstituir como se deram os fatos, $O$ que houve, o que não houve? Hoje é difícil reconstituir. Porém, como nesse tipo de manipulação o destinador-manipulador oferece ao destinatário objetos-valores os quais crê ser de interesse do sujeito manipulado, é possível inferir que a beleza, a vivacidade do sargento foram os objetos-valores utilizados para tentar a mulher. É o sargento, no papel de destinador-manipulador que vai tomando a iniciativa, vai se aproximando da mulher, a fim de que ela envolva-se com ele, realize a performance e, entrando em conjunção com o objeto-valor beleza, vivacidade, carinhos e afetos masculinos. Parece que ele pediu um maço de cigarros. Depois queria um vermute. Por fim pediu licença para escutar o noticiário esportivo...

A mulher, no papel actancial de destinatário, ao consentir a aproximação do sargento, difícil negar favores a sargentos, mormente um sargento daqueles, aceita a manipulação proposta pelo destinador-manipulador. Mais uma vez a mulher, sujeito ${ }_{2}$, é modalizada por um querer, todavia, a partir dessa manipulação, o querer domina, sobrepõe-se ao não-dever, tornando a esposa competente para realizar a performance. Resultado, eles se amaram de amor proibido, como Tristão e Isolda, como Paolo e Francesca. Pautadas nessas considerações, os exercícios abaixo foram sugeridos:

1 - Com base nos campos lexicais elaborados, responda:

a) O campo "enquadramento situacional" reitera a figura de um novo sujeito, o sargento. Com base nos campos lexicais "belo x feio" e "vivacidade $\mathrm{x}$ decadência", caracterize o sargento. 
b) As figuras dos campos lexicais "belo x feio" e "vivacidade x decadência", tanto do quadro I quanto do quadro II, reiteram aspectos físicos do homem e do sargento. Pontue as principais diferenças físicas desses sujeitos:

c) O campo lexical "relacionamento" aponta para o envolvimento da mulher com o sargento.

1) Quem exerce o processo de manipulação sobre o outro, a fim de envolverem-se, o sargento ou a mulher?

2) Como ocorre o processo de aproximação entre a mulher e o sargento?

3) O que a mulher encontra no sargento e que não encontrava no marido?

d) A convivência que o marido proporcionava à mulher, ainda no quadro I, era insossa, ité. Isso faz com que o marido comece a pesar para a mulher. A partir disso é possível inferir que a esposa queria ou devia ter um amante?

e) A mulher, mesmo sendo casada, mesmo não devendo, envolve-se com o sargento. O relacionamento dos dois fica em segredo. Retire do campo lexical "segredo" e "traição" figuras que reiteram a ideia de um relacionamento secreto.

Essa transformação, ou seja, o namoro com o sargento coloca a mulher em conjunção com seu objeto-valor, que não era necessariamente o sargento, mas a afetividade, a virilidade masculina que este lhe proporcionava, portanto, uma transformação de aquisição ou, ainda, de liquidação da privação. Sendo assim, a mulher é um sujeito realizado, pois realiza um fazer e adquire, por conjunção, o objeto-valor.

Ainda quanto às modalizações da mulher, sujeito ${ }_{2}$, convém destacar que além do querer, há outra modalização que a tornou competente para realizar a ação, o poder. Entretanto, essa modalização não é dada pelo sargento e, sim, pelo marido. É o esposo que dá conforto, boa alimentação para a mulher, condições essas que favoreceram a afluência da beleza feminina. É com os recursos financeiros do marido que a mulher passa a usar engenho $e$ arte, a fim de aumentar os dotes naturais. Depois de bela, a mulher é modalizada pelo poder, já que, possivelmente, foi a beleza que atraiu o sargento.

Depois dessa transformação, do envolvimento com o sargento, a esposa apresenta os seguintes enunciados de estados:

$$
\begin{aligned}
& \mathrm{S}_{2} \text { (mulher/esposa) } \cap \mathrm{O}_{\mathrm{v}} \text { (beleza) } \\
& \mathrm{S}_{2} \text { (mulher/esposa) } \cap \mathrm{O}_{\mathrm{v}}(\text { riqueza }) \\
& \mathrm{S}_{2} \text { (mulher/esposa) } \cap \mathrm{O}_{\mathrm{v}} \text { (afetividade/virilidade masculina) }
\end{aligned}
$$

Ao se envolver com o sargento, a esposa rompe seu contrato fiduciário com o marido, no que se refere à fidelidade. Porém, o marido enquanto destinador-julgador, não sabe desse rompimento, pois o relacionamento da esposa com o sargento está no âmbito do segredo, não parece, mas é. Daí não haver, ainda, sanção negativa por parte do marido, pois para ele a esposa não só parecia fiel, como também o era.

A transferência do sargento coloca, novamente, a mulher em disjunção da afetividade, da virilidade masculina, seu objeto-valor. Essa transferência do sargento, terceiro programa narrativo, é uma ação pautada no dever. Em função do cargo que ocupa, o sargento está a mercê de superiores que têm o poder de determinar os locais onde os militares devem trabalhar. Sendo assim, mesmo não querendo ir embora, afastar-se da amante, o sargento deve cumprir ordens dos seus superiores. Com a transferência, a mulher não deixa de ter um amante, mas fica sem os afetos, os carinhos, a presença viril do sargento. 
$\mathrm{PN}_{3}$

F: (transferência do sargento) $\left[\mathrm{S}_{4}\right.$ (superiores do sargento) $\rightarrow \mathrm{S}_{2}$ (mulher) $\cup \mathrm{O}_{\mathrm{v}}$ (vivacidade/beleza/virilidade masculina)]

Com a ausência do sargento, a esposa passa a transparecer para o marido um sofrimento, uma dor de amor. Diz que só quem ama conhece a dor da separação. Assim como ocorre uma mudança física da mulher com o casamento, a transferência do sargento traz à tona uma nova aparência. Os bonitos olhos da moça incharam de tanto choro. $O$ apetite diminuiu. Já lhe transparecia, por sob o rouge da face, a antiga cara de tísica. É essa nova fisionomia da esposa que desperta as suspeitas do marido. E há de ter sido esse desgosto, assim alardeado com pranto e fastio, que acabou por despertar as suspeitas do marido, não acordadas quando o amor florescia e tudo ainda eram rosas.

O marido, destinador-julgador, que acreditava ter uma esposa verdadeira, começa a duvidar disso. É a dúvida, a desconfiança que o levam a investigar até que ponto esse ser verdadeiro da esposa era, de fato, real. Passou o bodegueiro a vigiar a esposa; a lhe examinar os silêncios; a lhe escutar os murmúrios durante o sono. Essa investigação se prolonga até que o marido tenha certeza e descubra que a esposa não era verdadeira, como antes aparentava. As figuras, um postal, um livro com um nome de homem escrito em ambos, um escudo de corporação do sargento e as cartas representam as provas que o marido encontra, provas essas que dão certeza, para o marido que o traíam. A certeza de que ele era traído coloca em jogo outra modalidade veridictória, a esposa que, no viés do marido parecia e era fiel, perde o conceito de mulher verdadeira e ganha o status de esposa mentirosa, já que parecia, mas não era fiel.

Há, até então, a sanção cognitiva ou interpretação, com o julgamento do destinadorjulgador. Ele reconhece que a esposa, sendo infiel, não cumpriu o contrato estabelecido na ocasião do matrimônio. Falta, ainda, a sanção pragmática, mas esta não ocorre imediatamente, pois o marido guarda essa descoberta para si. Durante cinco meses o pobre revolveu dentro do seu magro peito doente o punhal venenoso do ciúme.

Até o término do quadro II, o marido enquanto destinador-julgador, continua a revolver o ciúme, a reler as cartas que a esposa recebia do amante. Depois de ler guardava tudo, corria à cozinha, engolia depressa uma colher de caldo, roía um pedaço de pão - seria impossivel comer direito com aquele amor de dois ladrões atravessado na garganta. Não há uma nova ação, apenas indícios de que a sanção pragmática ainda está por acontecer. Até que um dia houve provocação maior...

Cabe salientar que o narrador atribui a transferência do sargento ao destino. $E o$ destino, que não gosta de amores ilegais e costuma castigá-los com maus fados, fez a segunda intervenção: suscitou a transferência do sargento. Nesse prisma, a transferência passa a ser uma sanção. Há uma primeira sanção cognitiva, que julga o amor dos amantes como ilegal e, depois, há a sanção pragmática, um castigo aos amantes que é a transferência do sargento. É o destino, e não o marido, que realiza a sanção, pois julga e castiga a esposa por não estar cumprindo o contrato estabelecido com o esposo, já que tem sido infiel. $\mathrm{O}$ castigo do destino é colocá-la em disjunção de seu objeto-valor, os prazeres que a presença do sargento lhe proporcionava.

$\mathrm{Na}$ sequência, destacamos as questões proposta acerca da análise empreendida:

f) Considerando o campo lexical "sentimentos", como aparentava ser o relacionamento da mulher com o sargento?

g) Que figuras do campo lexical "auditivo" podem relacionar-se ao campo lexical "segredo"? 
h) A mulher, só depois de bela arruma um amante. Quem dá essas condições, esse poder, essa condição de beleza para que a mulher possa ter um amante?

i) A transferência do sargento acarreta várias mudanças na narrativa.

1) Considerando o campo lexical "sentimentos", como fica a mulher depois da transferência do sargento?

2) Qual a relação entre os campos lexicais: "sentimentos", "intensidade" e "revelação"?

j) A transferência do sargento é uma ação pautada no dever ou no querer?

k) Que relações pode haver entre os campos lexicais "visual", "auditivo" e "revelação"?

1) O campo lexical "correspondência" tem forte ligação com o campo lexical "revelação". Como são figurativizadas, no texto, as provas do relacionamento entre a mulher e o sargento?

m) $\mathrm{O}$ que faz o marido ao descobrir que sua esposa, mesmo parecendo não era fiel? Há alguma sanção (punição) por parte desse marido?

\section{Análise Semiótica e Atividades Desenvolvidas: o Conto no Viés da Sintaxe e da Semântica Narrativa - QUADRO III}

É no quadro III que se findam conto e crônica. Há nesse quadro o percurso da sanção. O marido traído, que já realizou a sanção cognitiva no quadro II, realiza, agora, a sanção pragmática, isso porque o coração do homem enganado saturou-se de ódio e ciúme até ao ponto de não poder contar mais nada. O marido, no papel de destinador-julgador, analisa, julga a atitude da esposa, no papel de destinatário e, sabendo de sua infidelidade sanciona-a negativamente. Essa sanção envolve um novo programa narrativo.

Manipulado pelo ódio e pelo ciúme, o marido traído, agora no papel de destinatário, aceita a manipulação proposta e realiza a performance. Essa performance, quarto programa narrativo, diz respeito ao assassinato que o marido comete contra um homem que vestia botinas pretas e calças cáqui.

$$
\begin{aligned}
& \mathrm{PN}_{4} \\
& \mathrm{~F}:(\text { atirar/matar })\left[\mathrm{S}_{1}(\text { marido }) \rightarrow \mathrm{S}_{4}(\text { um homem }) \cup \mathrm{O}_{\mathrm{v}}(\text { vida })\right]
\end{aligned}
$$

Para realizar a ação, ou seja, matar alguém, o marido traído precisava ser competente para tal. Como dito anteriormente, possivelmente o ódio e o ciúme, no papel de destinadormanipulador, manipulam o homem, no papel de destinatário a querer e dever matar, lavando, assim, sua honra. Além do dever, o homem é modalizado pelo poder, já que tem uma arma, retirou da gaveta do balcão um revólver que lá guardava há anos, e que fora empenhado por um devedor desaparecido. Além dessas modalizações, o marido possui um saber, pois ao atirar fica implícito que ele sabia manusear a arma. As modalizações descritas anteriormente tornam o marido competente para realizar a performance: daí a pouco se escutou um ruído de altercação, um grito de mulher e três tiros cortaram o ar, em explosões secas. Os tiros e o corpo de homem caído de borco são figuras que concretizam o percurso da ação, sinal de que alguém entrou em disjunção da vida: estava armada a tragédia: a mulher na calçada, de joelhos, aos gritos, o marido de revólver na mão, muito trêmulo, tentando soerguê-la, e, atravessado na porta, caído de borco, com o corpo para dentro da sala, um homem.

Ao solicitar que seu freguês chame a polícia, o marido realiza a sanção, pois há, nesse instante, a verificação do crime. E foi o próprio marido quem falou primeiro. Ergueu os olhos para o grupo apavorado, deu com a vista no seu freguês predileto, andou um passo, 
tapou com o próprio corpo a porta onde jazia o morto e pediu: - pode ir chamar a polícia. Esse último programa narrativo concretiza o percurso da sanção pragmática.

Atirar, matar um homem foi a maneira de o marido sancionar a esposa pelo não cumprimento do contrato estabelecido quando do casamento. Esse contrato é rompido quando a mulher arruma um amante, deixando de ser fiel ao destinador-manipulador, o esposo. $\mathrm{O}$ destinador-manipulador julga a ação do destinatário e sanciona, castigando a esposa com o assassinato, não dela, mas de um homem.

O marido explica, na polícia, que matou por ser um esposo enganado. No entanto, ele não mata nem a esposa, que o traía, nem o sargento, com quem a esposa o traía. Esse desfecho do conto só tem sentido quando compreendido no universo da crônica, ou melhor, se entendido como mais um caso de metonímia.

Quanto às atividades propostas, acerca desta última parte do conto, estas foram feitas no intuito de verificar como os alunos lidaram com a metodologia proposta dos campos lexicais. Além disso, tínhamos o propósito, a partir da reescrita do conto, de observar o sucesso, ou não, do trabalho de leitura realizado. Por último, sugerimos uma questão a qual objetivava perceber se os alunos conseguiriam reconhecer e explicar, pelo desfecho, um caso de metonímia.

1 - Observe as sugestões abaixo sobre possíveis hiperônimos, ou seja, prováveis agrupamentos de campos lexicais. Faça uma releitura do texto encontrando hipônimos, palavras que se relacionem e digam respeito aos hiperônimos sugeridos. Cada campo deve ser preenchido com mínimo de três figuras e máximo de cinco.

A) Actorialidade / Temporalidade / Espacialidade

B) Sensorial: Visual / Auditivo

C) Intensidade

D) Revelação

E) Sentimentos: Eufóricos / Disfóricos

F) Vida / Morte

2 - Conte, com suas palavras, como se desenvolve o conto, essa história que envolve um homem, uma mulher, um sargento e um carteiro. Não se esqueça de considerar os campos lexicais elaborados.

3 - Considerando o título do texto: Metonímia, ou a vingança do

enganado, explique por que o marido matou o carteiro?

\section{Considerações finais}

Considerando as dificuldades de leitura/compreensão dos alunos, nossa pesquisa procurou levar para a sala de aula atividades que possibilitassem aos educandos compreender a organização discursiva do texto e, a partir disto, reconhecer os sentidos mais imanentes.

Em relação aos Campos Lexicais, pelo trabalho realizado, foi possível perceber que essa segmentação pode contribuir no processo de interação do aluno com o texto, uma vez que possibilita ao aprendiz lidar com a materialidade discursiva. Esse contato mais demorado, mais "profundo" com o texto pode corroborar para que os educandos fiquem mais atentos a todas as figuras do texto e percebam que as escolhas do enunciador não são aleatórias, mas têm propósitos. É nesse momento que o professor pode atuar enquanto mediador, conduzindo os discentes na busca e construção do sentido, isso de forma reflexiva, crítica e interativa.

Procuramos, ainda, avaliar a viabilidade de aliar a montagem dos Campos Lexicais à Teoria Semiótica. Pelo que pudemos perceber, os alunos não apresentaram dificuldades, uma 
vez que realizaram os exercícios com facilidade. Isso nos leva a afirmar que a Semiótica pode ser utilizada, pelos professores, na elaboração de atividade de leitura em sala de aula.

\section{AGRADECIMENTOS}

Aos alunos da $8^{\mathrm{a}}$ série "A", de 2008 e 2009, e às professoras regentes da escola pesquisada pelo espaço concedido bem como pelas importantes contribuições na realização deste estudo, parcialmente divulgado neste texto.

\section{REFERÊNCIAS}

BARROS, D. L. P. de. Teoria semiótica do texto. 4. ed. São Paulo: Ática, 2005. Publicação original 1990.

BENVENISTE, E. Problemas de Linguística Geral II. São Paulo: Pontes, 1989.

FIORIN, J. L. Elementos de análise do discurso. 14. ed. São Paulo: Contexto, 2006. Publicação original 1989.

Paulo: Ática, 1999.

As astúcias da enunciação: as categorias de pessoa, espaço e tempo. 2. ed. São

INSTITUTO NACIONAL DE ESTUDOS E PESQUISAS EDUCACIONAIS ANÍSIO TEIXEIRA - INEP. Programa Internacional de Avaliação de Alunos - PISA. Disponível em: <http://www.inep.gov.br/internacional/pisa/>. Acesso em: 14 jan. 2009.

LIMOLI, L. Leitura semiolingüística do conto ' $O$ Búfalo' de Clarice Lispector. UNESP/ASSIS: Tese de doutorado, 1997.

LIMOLI, L.; GIACHINI NETO, E. Semiolinguiística e leitura do texto literário. Boletim do Centro de Letras e Ciências Humanas. UEL, p. 151-166, jul-dez 2001.

LIMOLI, L. et. al. Leitura do texto poético: uma abordagem semiótica. Mosaicos. UEMS, ano 1, n.1, p. 75-86, 2005.

ANEXO

\section{Metonímia, ou a vingança do enganado}

(Drama em três quadros)

Quadro I

Metonímia - a palavra me ficou na memória desde o ano de 1930, quando publiquei o meu livro de estréia, aquele romance de seca chamado $O$ quinze. Um crítico, examinando a obrinha, censurava-me porque, em certo trecho da história, eu falava que o galã saíra a andar "com o peito entreaberto na blusa". "Que disparate é esse?", indagava o sensato homem. "Deve-se dizer é: blusa entreaberta no peito". Aceitei a correção com humildade e acanhamento, mas aí o meu ilustre professor de Latim, Dr. Matos Peixoto, acudiu em meu consolo. Que estava direito como eu escrevera; que na minha frase eu utilizara uma figura de retórica, a chamada metonímia - tropo que consiste em transladar a palavra de seu sentido natural da causa para o efeito, ou do continente para o conteúdo. E citava o exemplo clássico: "taça espumante" - continente pelo conteúdo, pois não é a taça que espuma e sim o vinho. Assim sendo, "peito entreaberto" estava certo, era um simples emprego de metonímia. E juntos, numa nota de jornal, meu mestre e eu silenciamos o crítico. Não sei se o zoilo aprendeu a lição. Eu fui que a não esqueci mais. Volta e meia lá aplico a metonímia - acho mesmo que é ela a minha única ligação com a velha retórica. 
Faz pouco tempo, por exemplo, dei com uma ocorrência de metonímia prática: certa senhora nossa conhecida, há anos hospedada numa pensão, saiu de repente da casa e passou a ser inimiga mortal da senhoria. Indagada da gente por que aquela inimizade repentina, quando todos sabíamos que a dona da pensão era boa alma, lhe dava injeções, lhe emprestava a bolsa de água quente e a acudia nos seus acessos cardíacos, a ofendida explicou:

- O que eu não perdôo a ela é o telefone. Todo dia o telefone da copa me chamava eu ia ver, era trote.

- Mas não era ela que dava trote!

- Não. Mas de quem era o telefone?

Agora sei de outro caso de metonímia aplicada, que ainda é mais importante, pois se trata de caso de crime. Relação de causa e efeito, ou mesmo culpar o continente pelo conteúdo - qualquer dos dois está certo.

Assim $^{4}$ pois aconteceu numa cidade do interior - não conto onde, para não dar lugar a maledicência. Diga o pecado mas não diga o pecador.

Pois nessa cidade do interior havia um homem; não era velho, mas pior que velho, porque era gasto. Em moço sofrera de beribéri, o que lhe arruinou para sempre o futuro. Tinha as pernas fracas, o peito cansado e asmático, a cor terrosa, o olhar vidrado de doente crônico. Contudo era homem de algumas posses, casa própria com loja contígua, onde instalara o armazém; vivesse ele no Ceará, o armazém se chamaria bodega, em Pernambuco venda, no Pará mercearia, em São Paulo empório. E já que eu não quero designar o local do crime, qualquer nome desses serve. Bodega ou empório, era comércio, e quem tem comércio tem dinheiro; de jeito que, apesar de tão malajambrado, o nosso homem casou. Justiça se faça que não tentou a Deus com nenhuma beldade: procurou moça pobre, magrinha, operária numa oficina de roupas de homem. Diziam até que ela tinha cara de tísica. Mas não contava o prezado amigo com os efeitos da boa nutrição no metabolismo feminino. Sei que a cara-de-tísica, livrando-se das oito horas de trabalho à mesa do costura, passando a comer bem, em casa sua, a boa carne fresca, o seu bom tutu, a sua salada de pepino, os doces de lata, as doces laranjas da serra que o marido comprava aos centos para a freguesia, mudou como se fosse encantada. Começou a botar corpo, a aumentar as polegadas nos lugares certos - parece até que estava crescendo. $E$ as cores do rosto, então! Ainda mais que, com a afluência do dinheiro, deu para se vestir bem, se pintar, ondular o cabelo, usar engenho e arte a fim de aumentar os dotes naturais, pois não sei se contei que, de cara mesmo, ela não tinha nada de feia.

E assim bela e assim vestida e assim pintada e formosa, começou a lhe pesar o marido enfermiço, envelhecido antes do tempo. Que, mal fechava o armazém, tomava a janta de leite (tinha cisma de carne), pegava o jornal, sentava na cadeira-preguiçosa até a hora de ir para a cama. Não queria saber de cinema, nem de futebol, nem sequer de rádio. Até mesmo por amor não se interessava grande coisa, que aquele corpo franzino, amarelo, não era de pedir amores. Só a convivência morna, insossa, ité, como se diz em São Paulo.

E foi aí que o destino saiu dos seus cuidados e fez a primeira intervenção: suscitou um sargento.

(...)

\footnotetext{
${ }^{4} \mathrm{O}$ texto em negrito corresponde à primeira parte do conto.
} 


\section{Metonímia, ou a vingança do enganado}

(Drama em três quadros)

\section{Quadro II}

Claro $^{5}$, não era justo que a jovem esposa depois de recondicionada graças às finanças do marido tirasse vantagens dessa nova situação de mulher bonita, em prejuízo do supradito marido. Não era justo, mas este mundo vive de injustiças. E o sargento - quer fosse do Exército, da Aeronáutica, da Marinha ou dos Fuzileiros (não digo ao certo, firme meu propósito de evitar identificação) -, o sargento era simpático, era musculoso, era jovem, era formidavelmente marcial dentro da farda justa ao peito, o andar elástico, a fala ríspida habituada ao comando.

Aconteceu que, um belo dia, servia a dama ao balcão (segundo era costume do casal, enquanto o marido almoçava), quando sobreveio o sargento. O que houve, o que não houve? Hoje é difícil reconstituir. Parece que ele pediu um maço de cigarros. Depois queria um vermute. Por fim pediu licença para escutar o noticiário esportivo no rádio que tocava perto do balcão. Seria pretexto para se demorar ali, mas a moça consentiu. É difícil negar favores a sargentos, mormente um sargento daqueles. Contudo, naquele dia, além disso ele não pediu mais que olhares. Ou no máximo disse alguma palavra, mas murmurada tão baixo que a não ouviu o resto da freguesia presente, sempre atenta a mexericos.

Com três almoços o namoro pegara firme. E seguindo-se aos almoços uma gripe do marido, os dois caminharam muito além de namoro. Como se encontravam, onde e que horas, não se apurou. Basta que se diga que eles se amaram de amor proibido, como Tristão e Isolda, como Paolo e Francesca.

E o destino, que não gosta de amores ilegais e costuma castigá-los com maus fados, fez a segunda intervenção: suscitou a transferência do sargento.

$* * *$

Diz que só quem ama conhece a dor da separação. Os bonitos olhos da moça incharam de tanto choro. O apetite diminuiu. Já lhe transparecia, por sob o rouge da face, a antiga cara de tísica. E há de ter sido esse desgosto, assim alardeado com pranto e fastio, que acabou por despertar as suspeitas do marido, não acordadas quando o amor florescia e tudo ainda eram rosas.

Passou o bodegueiro a vigiar a esposa; a lhe examinar os silêncios; a lhe escutar os suspiros e os murmúrios durante o sono. Deu para fazer pesquisas e acabou descobrindo um postal e um livro com um nome de homem escrito em ambos - e com a mesma letra. Descobriu um escudo da corporação do sargento - o que provava que o objeto de suspiros, silêncios e murmúrios, além de homem era soldado. E tantas descobertas pequenas levaramno afinal à maior de todas, que era descobrir que o traíam. Porque descobrira as cartas, as cartas de amor que vinham com carimbo distante, por via aérea, assinadas com aquele nome fatal.

Durante cinco meses o pobre revolveu dentro do seu magro peito doente o punhal venenoso do ciúme. Como menino que descobre um ninho de pássaro e fica diariamente a vigiar escondido o número de ovos que aumenta, e depois os progressos do choco, assim conseguira o marido uma chave falsa para o cofre de guardados da mulher: era uma caixa de madeira do Paraná, com um pinheirinho recortado na tampa, que ele mesmo lhe dera durante a lua-de-mel, dizendo rindo: "Está aqui, para você guardar os seus segredos..."

\footnotetext{
${ }^{5} \mathrm{O}$ quadro II corresponde à continuação do conto.
} 
E a ingrata obedecera ao pé da letra.

Todos os dias, naquela hora fatal do almoço, quando a mulher o substituía no balcão, ele nem cuidava de comer. Era só correr ao quarto, abrir o camiseiro tirar a caixa de sob o monte de roupa branca, puxar do bolso a chavinha falsa e abrir ansiosamente a carta nova. $\mathrm{E}$ quando não havia carta nova, reler a velha, ou antes, uma das antigas, uma datada de $21 \mathrm{de}$ agosto, tão cheia de recordações realísticas, que até parecia diálogo de filme francês. Depois de ler guardava tudo, corria à cozinha, engolia depressa uma colher de caldo, roia um pedaço de pão - seria impossível comer direito com aquele amor de dois ladrões atravessado na garganta.

(...)

Até que um dia houve provocação maior...

Metonímia, ou a vingança do enganado

(Drama em três quadros)

Quadro III

$\mathbf{E}^{6}$ um dia, como dizíamos na semana passada, houve provocação maior ou o coração do homem enganado saturou-se de ódio e ciúme até ao ponto de não poder contar mais nada. Isso não se explicou. O que se sabe é que ele retirou da gaveta do balcão um revólver que lá guardava há anos, e que fora empenhado por um devedor desaparecido. Junto do revólver estava a caixa de balas. $O$ nosso amigo carregou a arma; e numa manhã de sol claro, eram dez horas em ponto, quando o armazém estava cheio de fregueses, viu-se que o bodegueiro apurava o ouvido, pedia licença aos presentes e transpunha a porta de comunicação da loja com a sua casa.

Daí a pouco se escutou um ruído de altercação, um grito de mulher e três tiros cortaram o ar, em explosões secas.

A freguesia alarmada correu, rodeou a esquina até à porta da frente da casa de moradia. Lá estava armada a tragédia: a mulher na calçada, de joelhos, aos gritos, o marido de revólver na mão, muito trêmulo, tentando soerguê-la, e, atravessado na porta, caído de borco, com o corpo para dentro da sala, um homem. Na posição em que estava não se lhe via cara nem torso, só as botinas pretas e as duas pernas, vestidas em calças cáqui.

E foi o próprio marido quem falou primeiro. Ergueu os olhos para o grupo apavorado, deu com a vista no seu freguês predileto, andou um passo, tapou com o próprio corpo a porta onde jazia o morto e pediu:

- Pode ir chamar a Polícia.

$* * *$

Na Polícia explicou que matara o homem porque era um marido enganado.

O delegado comentou:

- É raro. Em geral vocês matam as mulheres, que são mais fracas.

Mas o marido protestou, magoado:

- Não, eu não seria capaz de matar minha mulher. Ela é tudo que eu tenho no mundo, bonita, delicada, cuidadosa. Me ajuda no armazém, entende de contas, faz as cartas para os

\footnotetext{
${ }^{6}$ A parte do texto em negrito corresponde à parte final do conto. O restante do texto é um retorno à crônica. Disponível em: http://seer.fclar.unesp.br/casa
} 
atacadistas. Só ela pode fazer a minha comida - eu só como dieta especial, o senhor sabe. Como é que eu ia matar minha mulher?

- Então - ajudou o delegado - matou o amante dela.

O homem tornou a abanar a cabeça:

Também não. O amante era um sargento, que foi transferido e está longe. Além do mais eu só descobri o caso depois que ele viajou. Pelas cartas. Li tudo. Sei até uma de cor, a pior delas...

O delegado calava-se, sem entender, esperando o resto.

E o resto veio:

- Cada carta! Se cada carta daquelas tivesse vida, eu matava, de uma em uma. Fazia até vergonha - parecia coisa de livro. Pensei em tomar o avião e liquidar o sargento. Mas não tenho saúde para andar de avião. Pensei em matar um colega dele, aqui mesmo, para eles tomarem ensino e não transviarem mulher alheia. Mas tive receio de enfrentar a corporação toda - o senhor sabe como eles são unidos. Tinha entretanto que dar um jeito. Já sentia medo de acabar ficando doido. Não tirava aquelas cartas da cabeça; nos dias que não chegava uma, ficava aflito, mais aflito do que ela, que era a destinatária. Tinha que liquidar aquilo, não era? E hoje, afinal, carreguei o revólver, esperei a hora e, quando vi o desgraçado apontar do outro lado da rua, fui para casa, me escondi atrás da porta do quarto, esperando.

- O amante? - indagou o delegado, estupidamente.

O homem se irritou:

- Não, senhor. Não falei que não era o amante? Porém tinha culpa nas cartas. O sargento escrevia - mas era ele que trazia. Quase todo dia estava ali na porta, risonho, com o desgraçado do envelope na mão. Apontei o revólver e atirei três vezes. Ele caiu sem falar. Não, não era o amante, seu delegado. Não era o amante. Mas era o carteiro.

Recebido em: 15.09 .13

Aprovado em: 18.11 .13 